\title{
EVALUATION OF STATE AID AND ITS CREATED VALUE FOR DISABLED PEOPLE IN LITHUANIA
}

\author{
Laura GIRLEVIČIENĖ ${ }^{1}$ Alina KVIETKAUSKIENE $\dot{2}^{*}$ \\ ${ }^{1}$ Department of Economic Policy, Faculty of Economics and Business Administration, \\ Vilnius University, Vilnius, Lithuania \\ ${ }^{2}$ European Social Fund Agency, Vilnius, Lithuania
}

Received 08 July 2020; accepted 05 February 2021

\begin{abstract}
Countries facing social issues related to the disabled apply various measures to solve them, including State aid. However, the application of these measures does not always enable them to achieve the goals of state policy or to improve indicators such as the integration of the disabled into the labor market and reduction of social exclusion. In order to evaluate the effectiveness of State aid usage and influence on the implementation of disabled employment policies, this research develops a set of social and economic indicators to reflect the examined issue, allow for the assessment of the situation of the target group, and envisage areas of improvement. To evaluate the impact of State aid on the selected indicators, a simple linear regression analysis is performed. According to our evaluations, we establish that in order for the government to solve problems of poverty by employing disabled people, questions of financial capacity as well as the effectiveness of allowances for the disabled should be addressed. The expected effects of this measure are a growing number of employed disabled people and reduction of poverty and social exclusion among disabled people.
\end{abstract}

Keywords: State aid, employment of disabled persons, social inclusion, regression analysis, social indicators, economic indicators.

JEL Classification: H25, H71, J71, P43.

Online supplementary material: Supporting information for this paper is available as online supplementary material at https://doi.org/10.3846/jbem.2021.14471

\section{Introduction}

Although the aid of the European Union has admittedly strengthened the industrial sector and domestic market, it has been increasingly argued that it could be used more efficiently (Brandtner \& Vidoni, 2018). For example, Member States could distribute State aid better and in more targeted ways in order to strengthen the competitiveness of European industry and create sustainable jobs (Buelens et al., 2007; Kassim \& Lyons, 2013; Pisapia, 2014). States

*Corresponding author. E-mail: alina.kvietkauskiene@esf.lt 
should strive to distribute aid in ways that support activity that is unlikely to be funded by the financial market and that contributes to economic growth, competition, and the creation of sustainable jobs. However, achievement of these goals depends on economic approaches on the scale of all Europe (Quigley, 2009; Finke, 2020; Buelens et al., 2007; Iozia, 2016; Robins, 2018; Bourreau et al., 2020).

State aid in scientific literature is mainly analyzed from a competitive point of view (Bartniczak, 2013; Colomb \& Santinha, 2014; Crocioni, 2006; De Cock, 2018; Dietrich, 2015; Friederiszick et al., 2006; Haucap \& Schwalbe, 2011; Lagzdina \& Kristaps, 2018; Lopez, 2018; Nicolaides, 2018a, 2018b; Nicolaides \& Rusu, 2010; Radukić \& Vučetić, 2019; Reger \& Veljanovski, 2020; Tunali \& Fidrmuc, 2015), and there is a lack of research dedicated to the main policy objectives of State aid. This had an impact on the evaluation of the effectiveness of State aid for the employment of people with disabilities, as we were unable to support the results of our study with data from other researchers.

Another problem we encountered was the existence of differences in the treatment of the concept of disability. While disability is statistically treated as the subjective perceptions of an individual, in the case of State aid, persons with disabilities are recognized when they are approved by the system (Mazziotta et al., 2019; Parodi \& Sciulli, 2019). Also, there is no research and comprehensive evaluation of the situation in Lithuanian and the effectiveness of usage State aid for solving the employment problems of the disabled. It should be noted that Lithuania lacks a unified system for gathering all information about disabled people. The variety of authorities collects information about people with disabilities in different ways, which complicates the collection of data. Therefore, seeking to carry out such research, one of the main issues is the collection and unification of data.

The article addresses social problems related to the integration of disabled people into the labor market. The impact of State aid in promoting the integration of people with disabilities into the labor market on social exclusion, reflected in poverty, material deprivation and employment of people with disabilities, shall be investigated. Since scientific literature is dominated by state aid assessments as an object of competition policy, an economic-social dimension, which allows to supplement scientific discourse with insights into the effectiveness of state aid, is chosen in this article.

The purpose of the article is to evaluate the effectiveness of State aid provided in Lithuania aimed at increasing employment among disabled persons.

To achieve the key goals of the article, research objectives have been established. Firstly, an analysis of State aid usage and the dynamics of State aid usage in Lithuania is conducted. We then analyze changes in the employment of disabled persons and evaluate the statistics surrounding working-age disabled persons, both employed and unemployed. The novelty of research on this subject is reflected by the selection of established indicators, description of the employment situation among the disabled population, and complex evaluation of the effectiveness of the use of State aid provided in Lithuania aimed at increasing the employment of the disabled using linear regression analysis methods. After performing this evaluation, the results will be summarized, and the impacts of State aid on the employment of disabled persons and on economic indicators of the state are evaluated. 
In this article, State aid will be analyzed from two points of view - theoretical and practical. Theoretical analysis of State aid is performed in the first part of the article. Based on the results of this theoretical analysis, we develop an evaluative model for solving the social issues faced by disabled persons in terms of State aid in the second part. Practical applications of the model are provided in the third part of the article. The article ends with a summary of the analyzed information and provides conclusions concerning the effectiveness of State aid.

\section{State aid for disabled persons: promotion of employment and social inclusion}

In economic and state policy, there are cases in which the state creates exceptional conditions for market players in order to fulfill specific public interests. The adoption of these decisions is defined as the provision of State aid. Despite the importance and uniqueness of State aid, the politics of State aid draw less scientific attention than other targets of competition policy (Kassim \& Lyons, 2013). State aid has frequently been identified as a factor that limits competition, and thus, its proper application and impacts on specific areas must be thoroughly researched (Ginevičius et al., 2008).

Competition can be disrupted not only by actions of private organizations but by the interventions of member states providing any form of aid for entities. The Treaty on the Functioning of the European Union (hereinafter TFEU) forbids the provision of State aid, as it is antithetical to competition and incompatible with the internal market (Stanikūnas, 2009).

Nevertheless, State aid also has positive aspects, as it is viewed as a measure that helps the economy to adjust natural market failure (Martin \& Valbonesi, 2000; Pisapia, 2014). Having proven that state interference is beneficial for the market, ensures free movement, and does not breach in any way TFEU provisions, State aid can be interpreted as a positive measure (Buelens et al., 2007). In this case, in order to achieve certain governmental goals, State aid provisions can be adapted for the internal market or considered non-contradictory to the internal market. When implementing a State aid policy, it is important that it solves significant state problems, including economic, social, cultural, and other concerns. State aid can be the most cost-effective and optimal measure to correct market failure and achieve state goals that are not economic, e.g., social policy goals (Crocioni, 2006; Briglauer et al., 2019; Ferri, 2020).

Although Consolidated version of the Treaty on European Union and the Treaty on the Functioning of the European Union (2012) stipulates general State aid insurance, the aforementioned contract contains exceptions that enable the provision of such aid on certain conditions. The European Union, by allowing exceptions, determines three types of State aid according to aims that are considered compatible with the common market. These types include aid for increasing employment of disabled workers and persons that face unfavorable working conditions. According to the European Commission (2014), this type of aid is compatible with the common market and can be used to solve economic and political problems.

The state, in striving for the effective usage of national funds, must display interest in assessing returns on its investments in order to use granted aid efficiently. In this regard, State aid can be regarded as a state investment, as the state invests its resources in particular ways in pursuit of the economic well-being of the country. 
Based on information provided in the report of the World Health Organisation and World Bank [WHO] (2011), disabled people live in conditions of poverty more often compared to non-disabled people. Households in which disabled people live more frequently face various challenges such as poor diet, malnutrition, poor housing conditions, substandard sanitary conditions, decreased ownership of assets, and so on. Moreover, disabled people incur more expenses related to healthcare, as they are more vulnerable to illness (WHO, 2011). Conditions of poverty are primarily linked to income, which depends on a person's ability to participate in the economy. Although disabled individuals are provided with various payments, allowances, and pensions, those who are able to work and earn money have higher standards of living from a financial point of view. Much like the non-disabled, disabled individuals strive to receive financial remuneration in addition to disability allowance based on acquired knowledge and professional qualifications.

Throughout the implementation of European Union policies and strategies in this context, substantial attention has been paid to the inclusion of disabled people who have difficulties integrating into the labor market, and various assistance programs have been provided to help them establish themselves within it. From 2010 to 2020, European strategies to assist the disabled have focused on the provision of increased opportunities for disabled people to exercise their rights fully and comprehensively participate in social life (European Commission, 2010b). In order to achieve the aims of innovative, sustainable, inclusive growth as anticipated in the Europe 2020 strategy, the Commission highlighted the employment of disabled people as an area of priority and encouraged the provision of opportunities for a higher number of disabled people to earn a living in the open labor market. The Commission states that jobs ensure economic independence, enable the achievement of personal growth outcomes, and prevent poverty. The Council of Europe 2017-2023 disability strategy Human Rights: A Reality for All aims to ensure the equality and non-discrimination of persons with disabilities within society, increasing the availability of education and jobs for disabled people and create application schemes for aid when needed (European Council, 2017).

In order to improve social indicators, the state must form a social policy that increases the employment of non-disabled as well as disabled populations, encouraging them to start businesses in order to create jobs for the disabled, thus contributing to the growth of disabled employment as well as the reduction of social exclusion and poverty.

Various aspects of social exclusion have been analyzed in scientific literature. The key causes of social exclusion are related to rejection by parts of society, preventing people from full participation in social, economic, cultural, and political life (Bonanno et al., 2019; Kim et al., 2016; Mussida \& Parisi, 2019; Parodi \& Sciulli, 2019; Tobias \& Mukhopadhyay, 2017). Social exclusion is a complicated social phenomenon revealing itself as helplessness that is mainly caused by inappropriate social participation, lack of cultural and educational activity, and inadequate opportunities to use various provided services. These phenomena affect the most vulnerable populations, including disabled populations. According to researchers (Kim et al., 2016; Mussida \& Parisi, 2019; Parodi \& Sciulli, 2019; Tobias \& Mukhopadhyay, 2017), social exclusion is the outcome of disability.

Social exclusion is not simply a shortage of material resources. It is an emotional and psychological experience. However, poverty levels are primarily measured through the evalu- 
ation material characteristics. Scientific research states that people living below the poverty line experience the greatest amounts of social exclusion (Kim et al., 2016; Mussida \& Parisi, 2019; Parodi \& Sciulli, 2019; Tobias \& Mukhopadhyay, 2017). Growing levels of unemployment, decreasing incomes, and a lack of education are the main causal factors of poverty. The growth of poverty decreases consumer opportunities, resulting in diminished possibilities to participate in public activity, cultural life, and education. Low self-esteem, passivity, and forced delimitation can also significantly impact employment, which may influence individuals to sink even further into poverty. Consequently, poverty and social exclusion are two significant challenges in social and economic policy (Mussida \& Parisi, 2019; Tobias \& Mukhopadhyay, 2017). Social exclusion is more likely to be associated not with material deprivation but with one's ability to participate in social life, whereas poverty is linked to material well-being. Poverty can be defined as a combination of low income and various material hardships (Balvočiūte, 2019; Fremstad, 2009; She \& Livermore, 2009). It is important to note that material deprivation and income poverty are related to each other. Deprivation can affect the living standards of low-income persons, and lack of income results in deprivation. Hence, the likelihood of both groups to coincide is fairly high (Balvočiūtè, 2019; Bonanno et al., 2019). This dependence is typical not only in the context of society as a whole but also among distinct socially vulnerable groups. It is of great importance to improve standards of living for people who, due to health issues, find it difficult to integrate into society to the fullest extent. The interactions between social exclusion aspects have been measured and analyzed.

The European Union aims to evaluate the progress of countries toward poverty reduction and closing the social gap. Therefore, goals as well as measurement models have been developed to achieve these aims and help evaluate the levels at which individual countries are achieving them according to a standard set of criteria. Measurements of social exclusion are based on poverty risk and levels of material deprivation. Additionally, alongside evaluations of poverty level, living conditions and poverty risk levels of working people are measured (European Commission, 2010a, 2019a; Mussida \& Parisi, 2019).

The main source of social exclusion statistics in the European Union is the Statistics on Income and Living Conditions (EU-SILC) data collection. Every year, this analytical tool gathers and collects data from all EU Member States on the following topics: living conditions, income, social exclusion, accommodations, work, demographics, and education (Mazziotta et al., 2019; Mussida \& Parisi, 2019; Staškute, 2014). Moreover, EU-SILC collects and analyzes health indicators of populations that, due to illnesses, traumas, or other ailments, have restrictions of activity, State aid, or health care availability (Mazziotta et al., 2019; Staškutè, 2014). Additional data regarding the living conditions of specific populations, such as the disabled population, may be found in other areas of statistics - in this case, the area of healthcare. It should be noted that Lithuania, as a member of the EU, collects and analyzes analogous data on the state and is guided by requirements of the Eurostat database when collecting indicators.

Poverty risk indicators and material deprivation indicators are most commonly used to analyze the dynamics of population poverty. Both of these groups of indicators are also elements in measuring social exclusion. In scientific works, poverty risk level is defined as the fraction of people whose equivalized disposable income falls below 60 percent of the national 
median equivalized disposable income. This benchmark is related to income received by residents and demonstrates financial poverty (Balvočiūtè, 2019; Bonanno et al., 2019; Fremstad, 2009; Gannon \& Nolan, 2007; Mussida \& Parisi, 2019; She \& Livermore, 2009). Material deprivation indicators are not directly linked to monetary indicators. Instead, it is revealed in a more precise way by a particular ability to purchase goods, things that are considered to be necessities in order to reach a certain standard of living (Balvočiūtè, 2019; Mussida \& Parisi, 2019).

Material deprivation consists of indicators that define the ability of a population to ensure their material prosperity. If residents of a country face at least three of the aforementioned difficulties, the country is considered to suffer from material deprivation. Therefore, although indicators of material deprivation do not indicate direct financial difficulties, they do demonstrate shortages of particular necessary items and services in households. Each indicator is reflected in two dimensions: the ability to afford necessities (i.e., a washing machine, a car, a colour television, a telephone), and the opportunity to improve living conditions and decrease financial commitments (i.e., to pay mandatory contributions, debts, and bills; to maintain warm housing; to pay unexpected obligatory expenses; to eat meat and protein-rich food regularly; and to have holidays away from home for at least a week) (Balvočiūtè, 2019; Bonanno et al., 2019; Mazziotta et al., 2019; Mussida \& Parisi, 2019).

Indicators of quality of housing conditions are also associated with material deprivation (Ahrendt et al., 2018; Balvočiūtè, 2019; Fremstad, 2009; Kim \& Rhee, 2018; Mussida \& Parisi, 2019; Parodi \& Sciulli, 2019; Staškutè, 2014). These indicators can be divided into several groups. The first group includes indicators of housing infrastructure quality and residents' ability to allocate money to improvement of these conditions: installation of a shower and a bath, toilet facilities, and running water in accommodations. The second group of indicators is related to housing deterioration: leaking roof, humidity, and rotted flooring or windows. The third group of indicators relates to environmental factors that impact living conditions: insufficient space or lighting, noisy neighborhoods, environmental pollution, vandalism, and crime (Mussida \& Parisi, 2019).

One can conclude that indicators of poverty risk and material deprivation reflect residents' incomes and material situations and are two complementary factors and key tools for the measurement of social exclusion. These indicators help to evaluate not just rising risks of social exclusion but the economic well-being of the state as well.

The main reasons for the possible exclusion of disabled people are the following: lack of education, shortage of social relationships, accessibility to transport, and lack of employment or its absence. Moreover, limited possibilities to acquire goods and services, insufficient any training, lack of specialized services, and inadequacy of educational systems limit a person's opportunity to obtain necessary services. Furthermore, inefficient implementation of politics exacerbates social exclusion (Tobias \& Mukhopadhyay, 2017). It is important to note that statistically, concepts such as accessibility, active inclusion, and participation are theoretical concepts that are difficult to measure directly. Therefore, in order to monitor social exclusion, systems of statistic indicators must be developed to help assess these concepts appropriately (Mazziotta et al., 2019). 
Disability can be defined by several aspects. According to the United Nations Convention on the Rights of Persons with Disabilities, the disabled are considered to be people who have long term physical, psychological, intellectual, and sensory impairments, who encounter various obstacles, and whose comprehensive and efficient participation in society with others on the basis of equal rights is compromised (United Nations, 2010; Mazziotta et al., 2019). This definition of disability complies with the conceptual framework, in which a disabled person is defined as a person whose independence is limited due to their standards of living and the peculiarities of their activity context (Mazziotta et al., 2019; Parodi \& Sciulli, 2019; World Health Organization, 2018). An alternative approach is strictly institutional, according to which persons with disability are defined as such once approved by the system (Parodi \& Sciulli, 2019). The third approach, similar to the first, is independent decision, according to which disability is defined by taking into account the ways in which people understand the limitations of their everyday activities (Parodi \& Sciulli, 2019). This approach is applied when identifying the disabled by using EU-SILC data. Therefore, assessment of disability is a highly complicated task due to its complex nature and multiple dimensions.

In the EU-SILC data collection, like the Lithuanian statistics database, there is a minor module of health evaluation consisting of questions about perceived general health situation, chronic (long-term) diseases, and activity that is limited due to health issues. Limitations on everyday activity depend on health problems including permanent physical and psychological problems, disease, and disability. Data about limited activity due to health issues comprise self-assessments performed by respondents about their activity. A person with a chronic disease is not automatically identified as a person whose everyday activity is limited; in fact, everyday activity limitation for a period of least six months is a requirement for disability status (Mazziotta et al., 2019; Parodi \& Sciulli, 2019).

Mazziotta et al. (2019) compared the social exclusion of non-disabled and disabled citizens of EU countries using separate indicators derived from various studies related to the main areas of life - education and training, participation in the labor market, poverty and living conditions, social participation, and health conditions.

Kim et al. (2016) and Gannon and Nolan (2007) analyzed the levels of social exclusion among the disabled and the impacts of disability acquisition and loss related to social exclusion. To summarize the aforementioned arguments, the social exclusion of people with disabilities is influenced by the following factors: gender, academic position, economic situation, employment status, health conditions, and the degree and type of disability. Accordingly, these factors are interconnected (Kim et al., 2016).

\section{Methodology of comprehensive evaluation of state aid as a tool for the implementation of social policy}

In order to properly assess the effectiveness of State aid usage and impacts of the implementation of disabled employment policies, it is important to evaluate the indicators described in Section 1 that reflect the examined problem. Since measures of State aid are intended to solve social issues, when evaluating impacts, key social indicators are selected to represent the situation of the target group. The social problem examined in the research is related not 
only to an increase in employment among disabled persons but the improvement of living conditions for the target group as well.

Based on objectives set in the introduction of the article, we evaluate social policy implementation in Lithuania for the encouragement of employment among the disabled using granted State aid.

Data provided by institutions in Lithuania and the European Union related to the employment of the disabled, experiences with poverty, and levels of social exclusion as well as granted State aid within the period from 2008 to 2018 were collected, systematized, and examined. The chosen time frame allows us to monitor changes and trends in employment among the disabled and economic indicators consistently.

State aid for the disabled in Lithuania is aimed at working-age disabled persons, who are considered to be persons above 16 years old but not older than 67 years old. A linear regression model is applied in the research to evaluate factors' significance. The linear regression model as well as other linear models are often used in the evaluation of State aid, indicating the correlation between State aid and chosen indicators (Friederiszick et al., 2018; European Commission, 2014). When applying the linear regression method, it is important to carefully choose variables that are substantiated by economic theory.

To evaluate the impacts of State aid on selected indicators, a simple linear regression analysis is performed to determine the dependency between the two variables and. The linear dependence of the variable $Y$ on the variable $X$ is represented by the formula:

$$
y=b_{0}+b_{1} x+\varepsilon
$$

where $b_{0}$ and $b_{1}$ are unknown coefficients (constants) and $\varepsilon$ is random error. Random error may include measurement errors as well as unspecified and unexamined causes (Bilevičienè \& Jonušauskas, 2011; Čekanavičius \& Murauskas, 2014; Pabedinskaite, 2009).

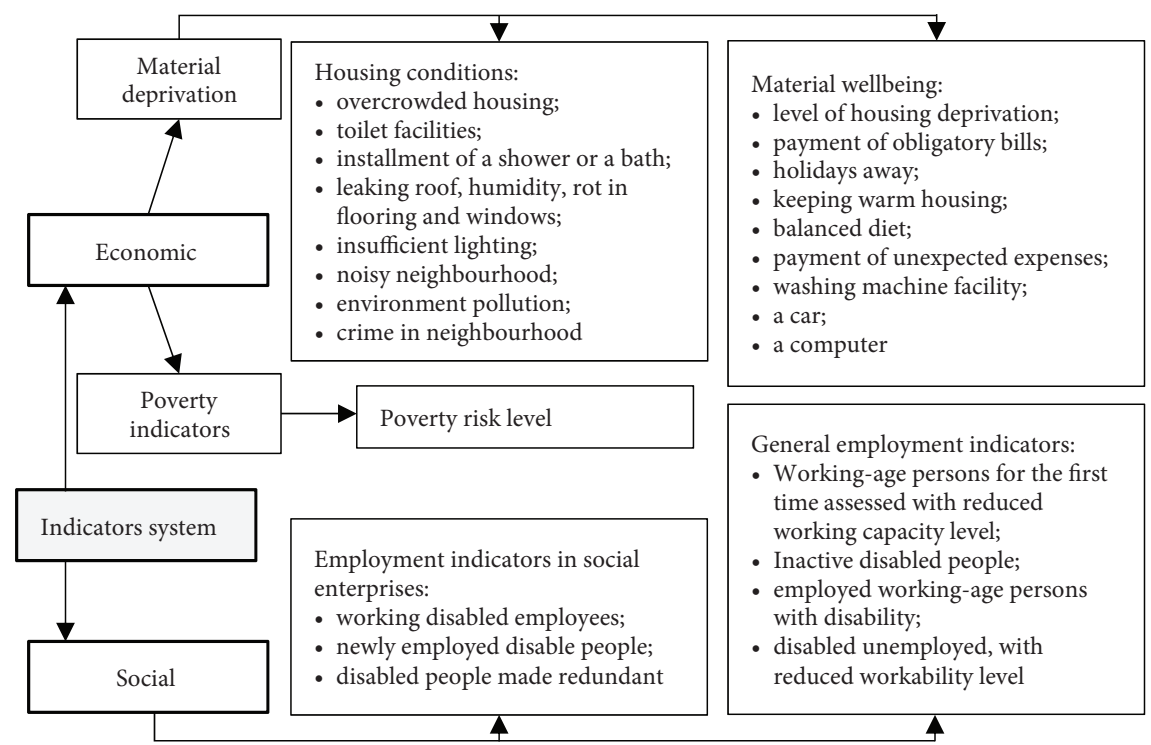

Figure 1. System of indicators applied in the evaluation (source: created by authors) 
Figure 1 displays the evaluative system of social and economic indicators we have established. This system is based on indicators of poverty and material deprivation compiled by the European Statistics on Income and Living Conditions (EU-SILC) tool as well as on data compiled by national authorities on the employment situations of people with disabilities.

Economic indicators include poverty indicators (poverty risk level of disabled people), indicators of material deprivation (ability to afford housing provisions, bills and unexpected expenses, holidays, a balanced diet, a warm home, necessary appliances, a car), and indicators related to living conditions (presence of a toilet, poor conditions of bathroom, insufficient lighting, pollution, noisy environment, poor neighborhood, overcrowded housing).

There are seven social indicators of employment levels among the disabled: working-age persons assessed to have working capacities of $0-55$ percent for the first time; employed working-age persons with disabilities; disabled unemployed assessed to have 0-55 percent working capacities; employees of social enterprises who belong to the disabled population; disabled persons newly employed in social enterprises; and disabled persons made redundant by social enterprises.

\section{Evaluation of state aid for the employment of the disabled: the Lithuanian case}

\subsection{Analysis of situation of disabled population in Lithuania}

Lithuania, like other countries in the European Union, grants State aid provided by the European Commission in order to solve various economic and social problems. The significance of State aid as a measure of support and policy implementation in the country has increased throughout the covered period. State aid provided in the country, according to it aims in 2008, comprised less than 0.2 percent of the GDP, whereas in 2018, this part made up almost 1.3 percent of the GDP (Figure 2).

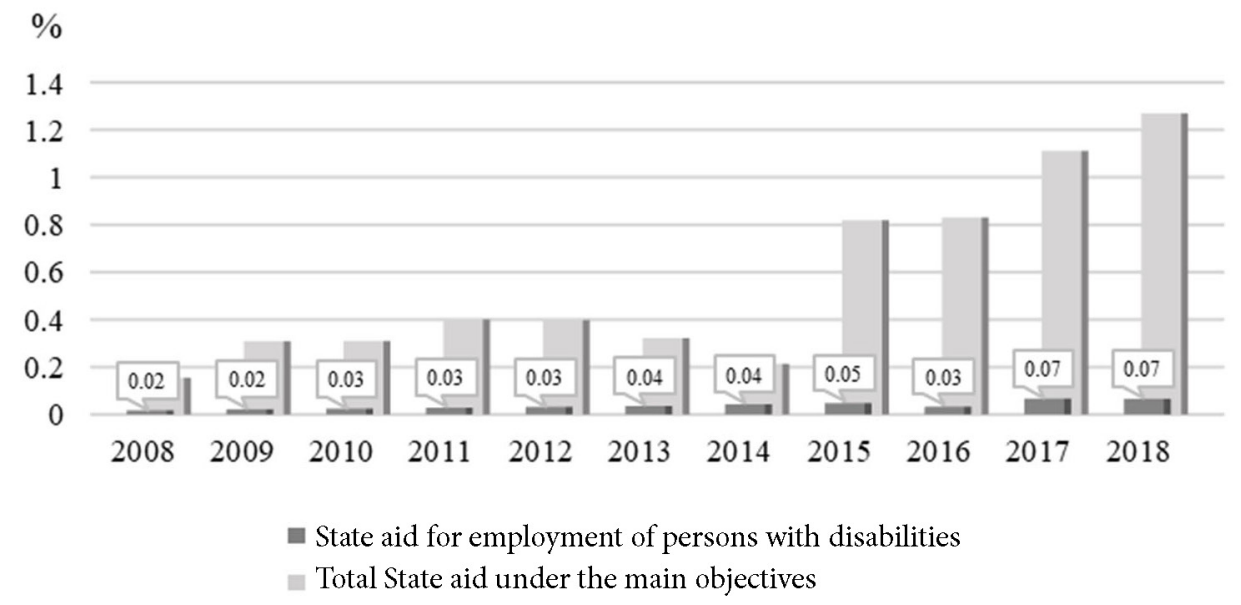

Figure 2. Comparison of State aid with GDP dynamics in Lithuania (per cent) (source: created by authors, based on data from the European Commision, 2019b) 
This change is the result of Lithuania's integration into the EU and goals of boosting economic areas of the country in accordance with the common EU rules. The growth of EU financial interventions has increased State aid usage throughout various areas, including the employment of disabled persons. Although the growth of State aid usage to increase the integration of disabled people into the labor market has been significant, employment aid constitutes a very small part due to the increasing extent of all State aid. Substantial portions of this aid are put toward achieving other goals of state policy through the use of State aid and subsidy.

According to the data presented by the EC, in the period from 2008 to 2018, State aid for employment in Lithuania was granted according to the General Block Exemption Regulation, which declares that the goals of State aid must comply with those of the EC. The General Block Exemption Regulation permits aid for employment when this aid is intended to increase the employment of populations who encounter difficulties integrating themselves into the labor market, such as the disabled population. Therefore, it is purposeful to review the situation of disabled people in Lithuania in a more detailed way in order to evaluate the effectiveness of State aid usage.

Within the period analyzed, the portion of disabled people in Lithuania increased from 8.1 percent to 8.7 percent, though the number of total citizens decreased. The number of inactive citizens has also fallen; over the period from 2008 to 2018, it decreased by 3.3 percent (Figure 3). Since 2010, the unemployment rate has decreased. Moreover, in the analyzed period, the number of employed persons has fallen; almost 700 people exited the labor market in the covered period.

The dynamics of demographic indicators among disabled people presented here reflect the situation of all disabled people in Lithuania. Nevertheless, State aid to increase the employment of disabled people is provided only to social enterprises that employ disabled peo-

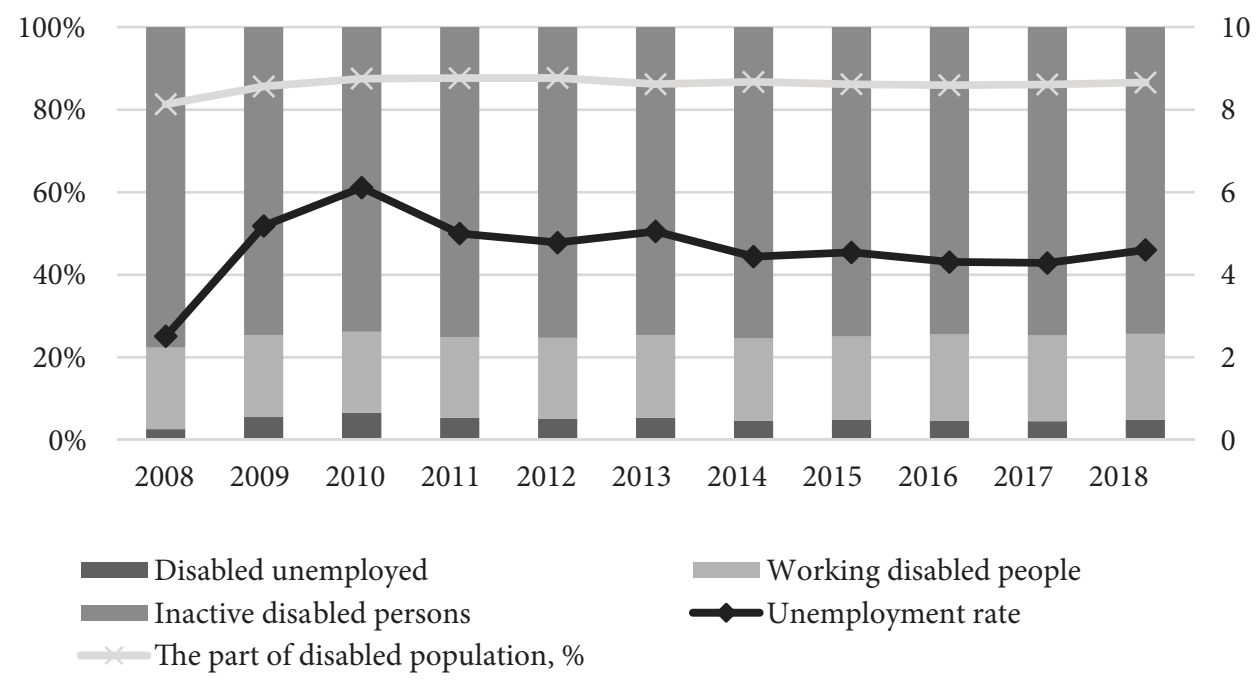

Figure 3. Dynamics of disabled people in Lithuania, per cent. (source: created by authors, based on Employment service, 2018; Ministry of Social Security and Labour, 2018) 
ple. This status is awarded to companies in which over 40 percent of their employees possess disabilities. Thus, these employees are presented with limited opportunities to integrate into society, as they work in an environment dominated by people with disabilities. However, employment issues among the disabled can be solved even in a rather closed labor market. Evaluation of the ability of disabled people to integrate into social enterprises reveals that level of integration in social enterprises is low. State aid serves a small group of disabled people, as a major portion of disabled people work in companies that do not have social enterprise status and are not able to apply for State aid. Therefore, in order to evaluate the effectiveness of State aid intended to increase the employment of disabled people in further detail, further linear regression analysis is performed and the effects of State aid on the economic and social problems faced by the disabled are evaluated.

\subsection{Impacts of state aid on economic and social problems faced by the disabled}

A model to evaluate the effectiveness of State aid as well as indicators reflecting the effectiveness of employment policies for the disabled was developed using a linear regression analysis method. In this analysis, indicators of State aid for the employment of disabled people are independent variables and the effects of state support are the dependent variable, as demonstrated in Figure 1. Analyzed indicators are divided into the following groups: employment indicators, disabled poverty indicators, common poverty indicators, societal integration indicators, and economic indicators.

The results generated by a successful employment policy not only include increases in the number of employed people with disabilities but increases in income as well, resulting in lower levels of poverty among the disabled and higher levels of social inclusion. Measurement of social inclusion is a complicated process that is significantly influenced by various economic and social areas. In this case, social inclusion is evaluated through the examination of poverty impact reduction and increases in employment. For these reasons, the social and economic indicators used to measure the impacts of State aid and describe the target group have been selected.

The social indicators included reflect the employment situation of the target group as accurately as possible and describe trends among active and inactive disabled people. In this case, it is possible to identify the economic state of the disabled using poverty and material deprivation indicators that are linked to received income directly and social exclusion indirectly. Having reviewed economic indicators, we observe that all indicators reflect deficiencies in the living conditions of disabled persons. Therefore, when evaluating effectiveness, decreases in value of these indicators are important.

Correlation analysis of economic indicators establishes that many indicators display an inverse correlation with State aid. One could argue that investments in employment among the disabled are efficient, as living condition indicators reflect positive impacts. When conducting initial tests of the suitability of the indicators according to the strength of the correlation coefficient, however, the assumption that State aid for the disabled is efficient cannot proven, as several indicators (poverty level, housing located in noisy neighborhoods, areas with high crime rates, warm housing, and state of housing regarding leaking roof or humid 
walls, as well as ability to acquire housing, afford a car, have holidays away, cover unexpected payments, and pay bills) display a frail and insignificant correlation and are thus removed from further analysis.

Other indicators (overcrowded housing, housing without a toilet, housing without a bath, poorly lit housing, and housing in polluted environments, as well as ability to purchase a computer, a washing machine, and to provide balanced nutrition) display statistically significant relationships with State aid. It should be noted that all moderately and strongly correlated indicators display decreasing trends or inverse correlations with increases in State aid, except the indicator of housing located in a polluted environment $(r=0.573)$. Diminished living conditions due to pollution generally reflect aspects of sustainable environmental policy and aims of making the world cleaner. Thus, this may be a result of the consequences of globalization, as State aid does not significantly impact the aforementioned indicator. After conducting additional aptitude tests, we validated the construction of a regression model according to criterion $\mathrm{F}\left(F=4.397\right.$, which is less than $\mathrm{F}$ critical $F_{\text {crit }}=5.117$ ) and criterion $\mathrm{t}\left(t=2.097\right.$, which is less than $\mathrm{t}$ critical $\left.t_{c r i t}=2.262\right)$.

Having selected statistically significant indicators, an analysis of the adequacy of these indicators was performed, estimating coefficients of determination $\left(R^{2}\right)$ (the value of which is not less than 0.25 ), the criterion $t$ (the absolute value of which cannot be less than $t_{c r i t}=2.262$ ), ANOVA $\mathrm{p}$ values not exceeding the values of the generally accepted error level 0.05 , and the F criterion, which may not be less than $F_{c r i t}=5.117$. According to the conducted tests, it was established that State aid for the employment of disabled people has a significant inverse effect on the following indicators: homes without toilets or running water, homes without bathrooms or showers, poorly lit housing, inability to afford a balanced diet, and lack of a washing machine.

Table 1. Regression equation models for economic indicators (source: created by authors)

\begin{tabular}{|l|c|c|}
\hline \multicolumn{1}{|c|}{ Dependent variables } & R-square & Regression model \\
\hline $\begin{array}{l}\text { Disabled people living in households without a toilet or } \\
\text { running water, per cent }\end{array}$ & 0.623 & $25.433+(-0.247) X$ \\
\hline $\begin{array}{l}\text { Disabled people living in household without a shower or } \\
\text { a bath, per cent }\end{array}$ & 0.585 & $23.984+(-0.226) X$ \\
\hline Disabled people living in dark, poor lit housing, per cent & 0.518 & $13.300+(-0.227) X$ \\
\hline $\begin{array}{l}\text { Disabled people who cannot aford to eating meat, fish or } \\
\text { analogous vegeterian food at least every second day, per } \\
\text { cent }\end{array}$ & 0.387 & $32.972+(-0.367) X$ \\
\hline $\begin{array}{l}\text { Disabled people who do not have a washing machine, } \\
\text { per cent }\end{array}$ & 0.663 & $7.659+(-0.158) X$ \\
\hline
\end{tabular}

Following verification tests, regression equation models were developed for the most appropriate indicators (Table 1). The created regression equations demonstrate that in order to change the material well-being of the disabled in a significant way, granting State aid of one million euros would decrease the values of indicators very slightly. If the State hopes to solve poverty by employing disabled people, issues of financial capacity must be evaluated, and 
the effectiveness of disability allowances must also be assessed. The impacts of payments are not evaluated in this research. However, if states grant larger subsidies without cutting social benefit payments for disabled people, financial burdens on the state budget may increase. By redistributing funds from the payment of benefits to grants, employers must be willing to pay competitive salaries to the disabled.

In order to evaluate the impacts of State aid on the targeted group, the effectiveness of social indicators was measured. Indicators of not only employed disabled individuals but unemployed and inactive disabled persons as well were selected for analysis, in addition to indicators reflecting the situation of disabled employees of social enterprises.

Analysis of general social indicators among the disabled reveals an inverse relationship between these indicators and State aid. According to some indicators (for example, the indicator of inactive disabled people $(r=-0.881)$ displays a strong inverse relationship with State aid), one could argue that State aid generates expected positive effects. Nevertheless, there is a strong negative correlation between State aid and the number of working disabled people $(r=-0.731)$, showing that the downward trend in inactive disabled people may be the result of other phenomena, e.g., tightened procedures of national employment level determination. The influence of other factors can also be seen in the moderate inverse relationship between State aid and persons diagnosed with reduced working capacity for the first time $(r=-0.647)$. The relationship between the State and the number of unemployed could not be established due to weak correlation $(r=-0.244)$.

Table 2. Models of regression equation for social indicators (source: created by author)

\begin{tabular}{|l|c|c|}
\hline \multicolumn{1}{|c|}{ Dependent variables } & R-square & Regression model \\
\hline $\begin{array}{l}\text { Working-age people who were assessed with reduced } \\
\text { working capacity 0-55 per cent for the first time }\end{array}$ & 0.419 & $20556.11+(-388.421) X$ \\
\hline Inactive disabled people & 0.776 & $191285.4+(-810.555) X$ \\
\hline Employed working-age persons with disability & 0.534 & $49309.852+(-84.662) X$ \\
\hline $\begin{array}{l}\text { Employees employed in social enterprises belonging to } \\
\text { a group of the disabled }\end{array}$ & 0.793 & $1272.904+228.689 X$ \\
\hline Disabled people newly employed in social enterprises & 0.708 & $545.435+117.559 X$ \\
\hline $\begin{array}{l}\text { Disabled people made redundant from social } \\
\text { enterprises }\end{array}$ & 0.787 & $109.239+113.473 X$ \\
\hline
\end{tabular}

When analyzing the relationship between disabled people working in social enterprises and State aid, one can observe that although these indicators are strongly statistically interconnected, the strong positive correlation $(r=0.887)$ between State aid and disabled workers that are made redundant by social enterprises demonstrates that State aid does not create permanence for disabled people when attempting to solve the employment problems of the population. A reliability test of the selected most suitable indicators was performed in the development of the regression model of social indicators, according to the same eligibility criteria that were used in evaluation of economic indicators. All indicators with strong correlations were positively assessed during the model fit check and included in the regression models (Table 2). 
All the detailed calculations, the values of correlation coefficients, $t$-values and other additional information is provided in the Annex 1. From the regression equations, one can conclude that one million euros in State aid will not have positive effects on the employment of the disabled, as granting larger subsidies will decrease the number of the employed disabled, even though these measures are intended to increase the number of employed disabled people. As the regression equations demonstrate, there is no impact of State aid on working people. Thus, Lithuania's main problem related to increasing employment of the disabled is not being solved. Evaluation of the impacts of State aid on the employment of disabled people in social enterprises and closed markets reveals that the growing number of these working people is static. A growing number of disabled people fired from social enterprises highlights employee turnover that could be related either to the health issues of employees and their limited capacities to work or due to the willingness of employers to ensure a permanent flow of subsidies for themselves.

\section{Conclusions}

This article's primary objective was to evaluate the effectiveness of State aid in Lithuania that aims to increase employment among the disabled based on a created system of economic and social indicators. Because State aid evaluations are not widely carried out among either policymakers or scientists, the results of such an evaluation may be considered novel research. In this study, State aid is treated as an investment into the solution of the social problems faced by the disabled in order to improve social as well as economic state indicators.

Using regression analysis methods, we determined that current State aid for the employment of disabled people does not generate expected improvements in the social inclusion of disabled people or help to combat poverty as intended. From the negative impact of State aid on the number of disabled people, one can observe that State aid does not encourage employment of the disabled in either the open market or the closed market.

Significant positive impacts of State aid are seen when the disabled are employed into social enterprises. Nevertheless, a clear trend in the redundancy of disabled people within these companies raises questions about the causes of such dynamics among indicators. One could argue that the growing volume of State aid for the employment of the disabled encourages social enterprises to expand by employing increasing numbers of disabled people. However, cases of fraud may occur among companies striving to ensure sustainable funding, resulting in the turnover of disabled employees within social enterprises.

The granting of State aid only to enterprises that meet special requirements without providing this type of aid to other companies that employ the majority of disabled people is insufficient, as this restricts the allocation of salaries and compensation for additional expenses to a relatively small target group. This study evidences that the implementation of state policies to reduce social exclusion and increase employment among the disabled remains ineffective. The economic situation of the state may influence the allocation of such limited resources. Following this systematic evaluation of the disabled population's integration into society through the use of State aid, it would be reasonable to evaluate the impacts of the economic capacity of the state on State aid in the future. Additionally, it is of great importance to 
look for other methods with which to promote employment among people with disabilities that are acceptable to both employers and disabled employees, simultaneously encouraging inactive people with disabilities to seek employment.

If it is established that State aid is not used effectively, investigations may continue to provide directions for improvements in the use of State aid. To this end, other countries can assess their social policies regarding people with disabilities and accordingly adopt best practices. For this purpose, multi-criteria evaluations may be used to analyze the established system of indicators reflecting the problem in question.

\section{References}

Ahrendt, D., Anderson, R., Dubois, H., Jungblut, J.-M., Leončikas, T., Sandor, E., \& Pöntinen, L. (2018). European quality of life survey 2016. Publications Office of the European Union. https://www.eurofound.europa.eu/publications/report/2017/fourth-european-quality-of-life-survey-overview-report

Balvočiūtè, R. (2019). Ar socialinès išmokos mažina gyventojų skurdą ? Poveikio lyginamoji analizė senosiose ir Rytų Europos šalyse. Socialinè teorija, empirija, politika ir praktika, 18, 23-45.

Bartniczak, B. (2013). Integrated assessment framework as a tool for identifying the type of state aid. Economic and Environmental Studies, 13(1), 23-33.

Bilevičienė, T., \& Jonušauskas, S. (2011). Statistiniu metodu taikymas rinkos tyrimuose. Mykolo Riomerio universitetas.

Bonanno, G., Chies, L., \& Podrecca, E. (2019). Poverty and material deprivation dynamic in Italy (Reasearch paper series, No. 2). DEAMS. https://www.openstarts.units.it/bitstream/10077/29162/1/DEAMS_RP_2019_2_BonannoChiesPodrecca.pdf

Bourreau, M., Feasey, R., \& Nicolle, A. (2020). Assessing fifteen years of State Aid for broadband in the European Union: A quantitative analysis. Telecommunications Policy, 44(7), 101974. https://doi.org/10.1016/j.telpol.2020.101974

Brandtner, B., \& Vidoni, D. (2018). State Aid evaluation. State of play and ways forward. European State Aid Law Quarterly, 17(4), 475-482. https://doi.org/10.21552/estal/2018/4/4

Briglauer, W., Durr, N. S., Falck, O., \& Huschelrath, K. (2019). Does state aid for broadband deployment in rural areas close the digital and economic divide? Information Economics and Policy, 46, 68-85. https://doi.org/10.1016/j.infoecopol.2019.01.001

Buelens, C., Gaelle, G., Roderick M., \& Matthew, J. (2007). European economy. Economic papers 286: The economic analysis of state aid: Some open questions. Directorate-General for Economic and Financial Affairs.

Čekanavičius, V., \& Murauskas, G. (2014). Taikomoji regresinè analizé socialiniuose tyrimuose. Vilniaus universiteto leidykla.

Colomb, C., \& Santinha, G. (2014). European Union competition policy and the European territorial cohesion agenda: An impossible reconciliation? State aid rules and public service liberalization through the European spatial planning lens. European Planning Studies, 22(3), 459-480. https://doi.org/10.1080/09654313.2012.744384

Consolidated version of the Treaty on European Union and the Treaty on the Functioning of the European Union. (2012). Official Journal, C 326, 26/10/2012 p. 0001-0390.

Crocioni, P. (2006). Can State aid policy become more economic friendly? World Competition, 29(1), 89-108.

De Cock, W. (2018). Economics of State aid control: Where law and economics meet. European State Aid Law Quarterly, 17(4), 565-569. https://doi.org/10.21552/estal/2018/4/15 
Dietrich, S. (2015). Donor political economies and the pursuit of aid effectiveness. International Organization, 70(1), 65-102. https://doi.org/10.1017/S0020818315000302

Employment service. (2018). Changes in the structure of the unemployed. https://uzt.lt/darbo-rinka/bedarbiu-strukturos-pokyciai/

European Commission. (2014). Commission staff working document. Common methodology for State aid evaluation. 28.5.2014. SWD(2014) 179 final. Brussels. https://ec.europa.eu/transparency/regdoc/rep/10102/2014/EN/10102-2014-179-EN-F1-1.PDF

European Commission. (2010a). EUROPE 2020. A strategy for smart, sustainable and inclusive growth. $\mathrm{COM} / 2010 / 2020$ final. Brussels.

European Commission. (2010b). European disability strategy 2010-2020. https://eur-lex.europa.eu/LexUriServ/LexUriServ.do?uri=COM\%3A2010\%3A0636\%3AFIN\%3Aen\%3APDF

European Commission. (2019a). Commission staff working document. Country report Lithuania 2019. 27.2.2019 SWD(2019) 1014 final. Brussels.

European Commission. (2019b). State aid scoreboard. European Commission - Directorate-General for Competition (DG COMP).

https://webgate.ec.europa.eu/comp/redisstat/databrowser/explore/all/COMP_TOP_2019?lang=en \&display=card\&sort=category

European Council. (2017). Council of Europe strategy for disability 2017-2023. https://rm.coe.int/16806fe $7 \mathrm{~d} 4$

Ferri, D. (2020). The role of EU State Aid law as a "Risk Management Tool" in the COVID-19 crisis. European Journal of Risk Regulation, (February), 1-20. https://doi.org/10.1017/err.2020.71

Finke, D. (2020). At loggerheads over state aid: Why the Commission rejects aid and governments comply. European Union Politics, 21(3), 474-496. https://doi.org/10.1177/1465116520916248

Fremstad, S. (2009, September). Half in Ten: Why taking disability into account is essential to reducing income poverty and expanding economic inclusion. Center for Economic \& Policy Research. https://www.cepr.net/documents/publications/poverty-disability-2009-09.pdf

Friederiszick, H., Głowicka, E., Gratz, L., Lünenbürger, S., \& Rosenfeld, A. (2018). Ex post state aid evaluation in environmental aid. European State Aid Law Quarterly, 17(4), 509-524. https://doi.org/10.21552/estal/2018/4/7

Friederiszick, H. W., Röller, L.-H., \& Verouden, V. (2006). European state aid control: An economic framework. Handbook of Antitrust Economics, 625-669. 712. https://scholar.google.com/citations?user=w_yScK4AAAAJ\&hl=en

Gannon, B., \& Nolan, B. (2007). The impact of disability transitions on social inclusion. Social Science and Medicine, 64(7), 1425-1437. https://doi.org/10.1016/j.socscimed.2006.11.021

Ginevičius, R., Podvezko, V., \& Bruzge, Š. (2008). Evaluating the effect of state aid to business by multicriteria methods. Journal of Business Economics and Management, 9(3), 167-180. https://doi.org/10.3846/1611-1699.2008.9.167-180

Haucap, J., \& Schwalbe, U. (2011). Economic principles of state aid control (Discussion Paper No. 17). Düsseldorf Institute for Competition Economics (DICE).

https://www.dice.hhu.de/fileadmin/redaktion/Fakultaeten/Wirtschaftswissenschaftliche_Fakultaet/ DICE/Discussion_Paper/017_Haucap_Schwalbe.pdf

Iozia, E. M. (2016). Europos ekonomikos ir socialiniu reikaly komiteto nuomonè dèl „Valstybès pagalbos imonems. Ar ji veiksminga ir efektyvi?” (Nuomone savo iniciatyva). Europos Sąungos oficialusis leidinys.

Kassim, H., \& Lyons, B. (2013). The new political economy of EU state aid policy. Journal of Industry, Competition and Trade, 13(1), 1-21. https://doi.org/10.1007/s10842-012-0142-9 
Kim, K. M., Kim, D., K., Shin, R. Y., \& Yoo, D. C. (2016). Social exclusion of people with disabilities in Korea. Social Indicators Research, 129(2), 761-773. https://doi.org/10.1007/s11205-015-1123-2

Kim, S., \& Rhee, S. (2018). Measuring the effects of employment protection policies: Theory and evidence from the Americans with Disabilities Act. Labour Economics, 54, 116-134. https://doi.org/10.1016/j.labeco.2018.08.001

Lagzdina, D., \& Kristaps, G. (2018). Baltics. State Aid to airport infrastructure in core TEN-T airports of three Baltic States and how they fit in limitations established by State Aid rules. European State Aid Law Quarterly, 17(1), 119-123. https://doi.org/10.21552/estal/2018/1/15

Lopez, J. J. P. (2018). Spain. Spanish supreme court rejects compensation to companies subject to State Aid recovery. European State Aid Law Quarterly, 17(4), 562-564.

Martin, S., \& Valbonesi. P. (2000). State aid in context. In G. Galli \& J. Pelkmans (Eds.), Regulatory reform and competitiveness in Europe (pp. 176-201). Edward Elgar Publishing Limited.

Mazziotta, M., Pallara, A., \& Solipaca, A. (2019). Using a composite index to measure social inclusion of people with disabilities. In A. Bianco, P. Conigliaro, \& M. Gnaldi (Eds.), Italian studies on quality of life (pp. 27-45). Springer International Publishing. https://doi.org/10.1007/978-3-030-06022-0_3

Ministry of Social Security and Labour. (2018). Disability statistics and dynamics. https://socmin.lrv.lt/ lt/veiklos-sritys/socialine-integracija/neigaliuju-socialine-integracija/statistika-2

Mussida, C., \& Parisi, M. L. (2019). Households at risk of severe material deprivation: The cases of Italy and Spain (pp. 1-28). DISCE - Quaderni del Dipartimento di Scienze Economiche e Sociali dises142, Università Cattolica del Sacro Cuore, Dipartimenti e Istituti di Scienze Economiche (DISCE).

Nicolaides, P. (2018a). Is there a need for a new concept of "Ex-ante Creditor"? European State Aid Law Quarterly, 17(3), 368-374. https://doi.org/10.21552/estal/2018/3/6

Nicolaides, P. (2018b). The compatibility of State Aid with the internal market. European State Aid Law Quarterly, 17(4), 534-545. https://doi.org/10.21552/estal/2018/4/9

Nicolaides, P., \& Rusu, I. E. (2010). The finanical crisis and state aid. The Antitrust Bulletin, 55(4), 759-783. https://doi.org/10.1177/0003603X1005500404

Pabedinskaitè, A. (2009). Kiekybiniai sprendimu metodai. I dalis. Koreliacinè regresinè analizè. prognozavimas. Vilniaus Gedimino technikos universitetas. https://doi.org/10.3846/791-S

Parodi, G., \& Sciulli, D. (2019). Disability and social exclusion in Italian Households. Social Indicators Research, 144(2), 767-784. https://doi.org/10.1007/s11205-019-02068-1

Pisapia, A. (2014). The role of EU State Aid policy in enhancing the development of the industrial sector. Privredna kretanja i ekonomska politika, 23(2), 45-65.

Quigley, C. (2009). European state aid law and policy. Hart Publishing.

Radukić, S., \& Vučetić, V. (2019). Comparative analysis of state aid and competitiveness of the Republic of Serbia and the neighbouring countries. Journal of Central Banking Theory and Practice, 8(3), 21-38. https://doi.org/10.2478/jcbtp-2019-0022

Reger, A., \& Veljanovski, C. (2020). The economics used in assessing state aid cases. https://doi.org/10.2139/ssrn.3518158

Robins, N. (2018). Ex post State aid analysis: First impressions. European State Aid Law Quarterly, 17(4), 473-474. https://doi.org/10.21552/estal/2018/4/3

She, P., \& Livermore, G. A. (2009). Long-term poverty and disability among working-age adults. Journal of Disability Policy Studies, 19(4), 244-256. https://doi.org/10.1177/1044207308314954

Stanikūnas, R. A. (2009). Konkurencijos politika: teorija ir praktika. Leidykla TEV.

Staškutė, I. (2014). Su sveikata susijusios gyvenimo kokybės samprata, stebėsenos ir vertinimo metodai bei reikšmè sveikatos politikoje. Health Policy and Management, 1(6), 7-19.

https://doi.org/10.13165/SPV-14-1-6-01 
Tobias, E. I., \& Mukhopadhyay, S. (2017). Disability and social exclusion: Experiences of individuals with visual impairments in the Oshikoto and Oshana regions of Namibia. Psychology and Developing Societies, 29(1), 22-43. https://doi.org/10.1177/0971333616689203

Tunali, Ç. B., \& Fidrmuc, J. (2015). State Aid policy in the European Union. Journal of Common Market Studies, 53(5), 1143-1162. https://doi.org/10.1111/jcms.12247

United Nations. (2010). United Nations Convention on the rights of persons with disabilities and its optional protocol. https://e-seimas.lrs.lt/portal/legalAct/lt/TAD/TAIS.335882

World Health Organization. (2018). International Classification of Functioning, Disability and Health (ICF).

World Health Organization \& World Bank. (2011). World report on disability 2011. World Health Organization. https://apps.who.int/iris/handle/10665/44575 